\title{
Investigation of Market Factors That Affect Customers' Buying Attitude towards Apartment Buying: An Opportunity Analysis from Bangladesh Perspective
}

\author{
Dr. Mostofa Kamal ${ }^{1}$, Dr. Md. Omar Faruk Sarker ${ }^{2} \&$ Shah Alam Kabir Pramanik ${ }^{3}$ \\ ${ }^{1}$ Adviser, Department of Real Estate, Faculty of Business and Economics, Daffodil International University, Dhaka, \\ Bangladesh \\ ${ }^{2}$ Professor, Department of Marketing, Faculty of Business Studies, Rajshahi University, Rajshahi, Bangladesh \\ ${ }^{3}$ Lecturer, Department of Business Administration, Faculty of Business and Economics, Daffodil International \\ University, Dhaka, Bangladesh \\ Correspondence: Shah Alam Kabir Pramanik, Lecturer, Department of Business Administration, Faculty of Business \\ and Economics, Daffodil International University, Dhaka, Bangladesh. E-mail: kabir.bba@diu.edu.bd
}

Received: April 6, 2016

Accepted: May 5, 2016

Online Published: May 10, 2016

doi:10.5430/ijba.v7n3p153

URL: http://dx.doi.org/10.5430/ijba.v7n3p153

\begin{abstract}
This study has investigated market factors that have been changing the attitude of Real Estate buyers in Bangladesh and ultimately creating the opportunities for Real Estate developers and marketers. The paper also has examined relationships among the market factors and buying attitude. This study has aimed at investigating the impact of customers' buying attitude on buying intention. Total twenty-four (24) attributes have been taken into consideration in designing questionnaire for the study. A questionnaire survey method is used with 200 respondents and response rate of 76.5 percent. Initially an exploratory factor analysis has been directed using SPSS (version 21). We have explored four market factors where cultural changes, land problem, urbanization and population pressures and finally raising prices level of building materials that have acted as antecedents of customers' buying attitude and created opportunities for the industry. After that, CFA has been carried out to confirm the factors. Structural Equation Modeling (SEM) has been used to test both the proposed model and hypothesized relationships among the constructs. It has found that land problem, urbanization and population pressures have created opportunities for Real Estate industry and that have significant impact on customers' buying attitude except the cultural changes and raising price level. It has also found that buying intention is strongly influenced by buying attitude of the customers. The proposed model also has an acceptable fit to the data. Real Estate developers, marketers, policy makers can use the findings to better understand, segment and satisfy the customers. Therefore the findings of the study will definitely help in building successful marketing strategies as well as achieving sustainable development of the sector. The study may be limited by its focus on a geographic section of the Bangladeshi Real Estate market.
\end{abstract}

Keywords: real estate, market factors, buying attitude, opportunities, real estate marketing

\section{Introduction}

As housing is the basic need of human being, it is expected that as a country becomes more urban, more houses will be needed to accommodate the increasing population in urban centers. Bangladesh is a densely populated country. The current trend of urban growth in Bangladesh is about 5-6 percent per annum (REHAB, 2013). At present 28 percent people live in urban areas which are expecting to be 34 percent in 2025 (The Daily Ittefaq, May, 2013). Dhaka city approximately accommodates a vast population of over 16.6 million with the estimated $4.7 \%$ growth rate per annum. There is a direct relationship between urbanization and demand for houses (Mollah, Haque and Pasha, 2009). Some tremendous changes have been taken place in the Real Estate industry that have changed buyers buying attitude and created opportunities for the Real Estate sectors. Now people prefer to buy ready apartment from developers than purchase land for building their own houses (Khaled, Sultana, Biswas and Karan, 2012; Mohiuddin, 2014; Mollah, et al., 2009). Cultural changes have been taken place such people would like to intend in single family unit, get project facilities and enjoy apartment culture (Bony and Rahman, 2014; Barua, Mridha and Khan, 2010; Mollah, et al., 2009). Due to urbanization, rising house rent, scarcity of land, high price of land, hazards in land 
purchasing, high cost of land registration, re-structuring of households to single family units, and high price of building materials, some dramatic changes have been occurred in the Real Estate industry that has changed the attitudes of the people of Bangladesh (Bony and Rahman, 2014; Mohiuddin, 2014; Khaled, et al., 2012; Zadkarim and Emari, 2011; Barua, et al., 2010; Mollah, et al., 2009). That's why people turn to Real Estate companies who are providing ready flats or apartments. In response, Real Estate business has enjoyed a boom over the years with growing rate (13.77\% in 2013, Bony and Rahman, 2014). In Bangladesh approximately 7 million people have been facing housing deficiency where 4 million in the urban areas and 3 million in the rural areas. To meet up the increasing housing need many private Real Estate developers with very few provision of government housing have been trying to meet the demand of housing for the last more than twenty years in Bangladesh. Although there is huge demand in the market for new accommodations, there is an acute shortage of excellent Real Estate developers. This in turn indicates the lack of good institutions in the housing and real estate value chain, from land developers to builders to financiers. This also indicates the bright prospect for Real Estate institutions in public and private sector. As Real Estate sector is growing in Bangladesh, the competition in the Real Estate sector becomes intense. To sustain in the competitive market place the Real Estate marketers have to keep in mind that the buying behavior of buyers in purchasing apartment would be considered high involvement products that require complex decision making (Haddad, Judeh and Haddad, 2011). Buying an apartment is one of the most significant economic decisions that people make, and it requires gathering a lot of information regarding its features, qualities, facilities, design, prices and environments (Haddad, et al., 2011; Zadkarim and Emari, 2011; Kiefer, 2007). In Bangladesh it happens in most of the cases that people purchase an apartment by investing or spending all of their lifelong savings. The success of Real Estate marketing depends on properly analyzing the buying behavior of Real Estate customers. To know about the needs of customers it is unavoidable to understand the changes that have taken place in the industry and market factors and variables that stalwartly influence the customers' buying attitude and created opportunities for Real Estate sector.

\section{Literature Review}

Numerous studies have been conducted on the Real Estate sector all over the world. Although enormous studies have been undertaken till now in Bangladesh unfortunately almost all of the studies are conducted on recent trends of Real Estate sector, problems and prospects, challenges and Real Estate financing. Most of the studies were conducted on secondary data. Most pivotal parts of the industry are customers. So there is a scope for conducting a comprehensive study on market factors that have changed the buyers' attitude and buying intention. What factors have changed the buyers' buying attitude and created opportunities for Real Estate sector in Bangladesh? Purchasing an apartment is a crucial decision for every customer in the Bangladesh because sometimes customers spend their whole-life savings to buy an apartment. Extraordinary studies have been conducted on location and size preferences (Labib, et al., 2013); customer perception and expectation (Khaled, et. al., 2012) and the dimensions of customer satisfactions and services (Preko, Agbanu and Feglo, 2014; Khaled, et al., 2012; Zadkarim and Emari, 2011a; Zadkarim, et al., 2011b; Leiser and Ghor, 2011; Shahin, Jarib and Samea, 2010; Lee, Chen, Huang, Chang and Udomjarumanee, 2009).

The studies on recent trends of Real Estate sector in Bangladesh brought into some causes that act as catalysts for booming of the Real Estate sector. The grounds for flourishing and dramatic changes in the Real Estate sector are urbanization, rising house rent, scarcity of land, high price of land, increasing the price of land (20 to 50 times in the last 15 years, Hasan, 1991, Labib, et al., 2013) lack of public supports (Labib, et al., 2013) act as catalyst for real estate boom previously, hazards in land purchasing, high cost of land registration, re-structuring of households to single family units, and high price of building materials that have been occurred in the Eeal Estate industry and changed the attitudes of the people of Bangladesh (Bony and Rahman, 2014; Labib, et al., 2013; Khaled, et al., 2012; Dewri, et al., 2012; Leiser and Ghor, 2011; Barua, et al., 2010; Khan and Barua, 2009; Islam, 2008. The researchers also showed now people of Bangladesh are interested to buy a ready apartment from the developers than purchase land for building their own houses (Khaled, et al., 2012; Mohiuddin, 2014).

Mohiuddin (2014) carried out an outstanding study on the Real Estate business in Dhaka city: growth and contribution to the economy of Bangladesh. This study showed the current scenario of Real Estate business in Bangladesh, trends, contribution of this sector to GDP, urbanization growth rate and finally reasons for changing the attitude of Real Estate buyers. Due to increased land cost as well as construction cost and other reasons such as reluctance of individuals to spend time and energy in house construction, increased awareness of apartment living and western influence. As a result, apartment-owing is becoming increasingly popular and demand. Apartment culture has been growing up in Bangladesh. Rapid increase population in the city, scarcity of unoccupied lands in important parts of the city, very high price of land, hazards involving purchase of land, profit motives of land owners, increase of remittance inflows in that finance many purchase of flat/apartment, re-structuring of households to single 
family units, standard of security and other services in apartments are the major variables that changes the attitude of Real Estate customers. The study also showed how with a rising population and increasing housing demand, apartment culture has grown up in Bangladesh.

Bony and Rahman (2014) have performed a research on practice of Real Estate business in Bangladesh: prospects and problems of high-rise building. This paper identified some recent trends of Real Estate sector like increasing the population growth and urbanization, increasing the number of city dwellers that has been influencing the growth of Real Estate sector more rapidly. They showed these market factors have been changing the attitude of the Real Estate buyers and creating the opportunities for the industry.

The study of Labib, Bhuiya and Rahaman (2013) has showed the Real Estate buyers preferences for location and factors considering for buying an apartment. Secondly the study tried finding out the existing market conditions. This survey explored that Real Estate sector is growing now. Due to urbanization, high population growth, the scarcity of open and vacant land, hazards in land purchasing, increasing the price of land (20 to 50 times in the last 15 years, Hasan, 1991) lack of public supports act as catalyst for Real Estate boom previously.

Khaled, Sultana, Biswas and Karan (2012) conducted survey on customer perception and expectation. In this study they tried to identify the dimensions of customer perception and expectations and with the help of that dimensions they measure the customer perception about apartment in the Chittagong regions. They showed the recent trends of Real Estate sector of Bangladesh. People are now not interested to buy a land for building their own house due to high price, Insufficiency of land, High cost of land registration, and high price of building materials. That trend creates the opportunities for Real Estate sector. Preferable services facilities and project facilities in the apartment encourage the buyers to buy.

Dewri, Amin, Sen and Faridi (2012) carried out a comprehensive study that covered a broad area of Real Estate sector of Bangladesh. They have found the reasons of increasing tendency of buying Real Estate apartment in Dhaka city. Rapid increase in the population of the city, scarcity of unoccupied lands in important parts of the city, very high prices of land, hazards involving purchase of lands, profit motives of the land owners, increase of remittance inflows in that finance many purchases, re-structuring of households to single family units are the recent changes in Real Estate industry that has been creating the sector more profitable.

Barua, Mridha and Khan (2010) conducted a study on "Housing Real Estate sector in Bangladesh present status and policies implications". In this paper they tried to depict the current picture and economic contribution of Real Estate sector, growth rate, market structure, financing condition and future potentiality of the Real Estate sector in Bangladesh. Rise in house rent, increasing demand for housing, getting easy financing facility, rapid urbanization (The rate of urbanization is estimated to be 5-6\% annually for Bangladesh (REHAB, 2004), About $25 \%$ of the people of Bangladesh is now living in urban areas and 34\% will be living by 2015 (REHAB, 2004) and 50\% by 2025 (Singha, 2001), inadequacy of land, hazards in purchasing land, huge time and energy are required for maintenance and construction of buildings, western culture and many other factors leads the people to buy an apartment rather than building houses on their own. They also showed that customers are expecting diversified products that indicate project facilities, standardized services and security are preferred by customers to purchase an apartment. These current trends are creating huge scope for this sector to grow.

Islam, M. T. (2008) conducted a thesis on "Real Estate market in Bangladesh: Development and current practice". In this paper he tried to find out the comprehensive picture of Real Estate market in Bangladesh. He showed the recent trends and the reasons of booming of the Real Estate business in Dhaka (why did it happen?). Land scarcity, hazards in purchasing the land, population growth, urbanization and Migration, rent variation, hazards in construction building, lack of social security, public sector failure, increased population, complementary services, decrease in the bank interest rate etc are act as a catalyst for booming the Real Estate industry in Bangladesh.

\section{Conceptual Framework and Hypothesized Research Model}

Now apartment choice decision has been an important area of study in the Real Estate marketing literature for decades. As consumer behavior is too complex scholars have not been agreed upon that a single model or theory can fully explain the consumer decision making. Based on the extensive literature review we have found tremendous changes have occurred in the Real Estate industry. Some market factors and variables have changed the customers' attitude and buying intention that ultimately created the opportunities for the Real Estate developers and marketers. Based on literature review and opinion of industry expert we have developed a conceptual framework. 


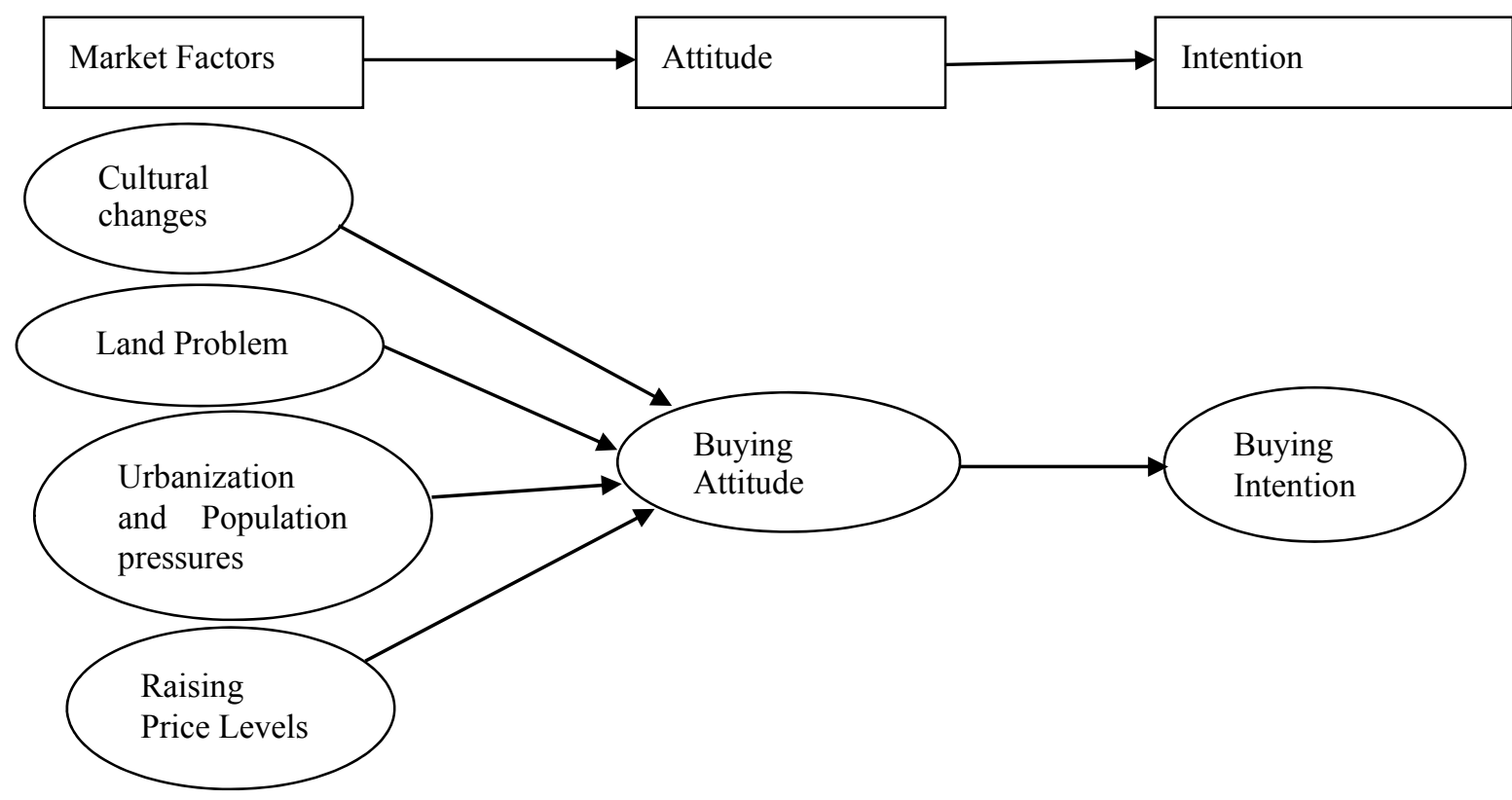

Figure 1. Hypothesized model of real estate buyers' buying intention

The hypothesized model indicates that market factors have an impact on customers' buying attitude. And Buying attitude has an impact on buying intention. The recent trends or market factors such as cultural changes, land problem, rapid urbanization and population pressure, raising the price level of building materials are tremendously affecting the buying attitude.

Cultural Changes (CC): Culture is the set of values, beliefs, ideas, norms, morals, and customs that are transmitted and shared in a given society. Culture is dynamic in nature. In Bangladesh the culture has changed that has brought revolutionary changes in the Real Estate industry. The major changes from joint family to nuclear family (re-structuring of households to single family units), western culture, intends to be single family in urban areas have increased that ultimately increased the demand of apartment. Here we have considered four attributes of cultural changes namely Re-structuring of households to single family units, western culture, intends to be single family (SFU); Apartment culture/ influence of western culture (AC); Project facilities are demanded (PFD); Standard services and security in the apartment (SSS) that are affecting the customers' buying attitude. These variables have been showed by different scholars (Bony and Rahman, 2014; Mohiuddin, 2014; Khaled, et al., 2012; Zadkarim and Emari, 2011; Barua, et al., 2010; Mollah, et al., 2009).

Land Problem (LP): We know demand for housing in urban areas has been increasing terrifyingly but land is fixed. As land is fixed that price of land is skyrocketing. So people are reluctant to buy land for building their own apartment. Buyers are going to apartment developers and marketers to buy an apartment. Various reasons related with land such as Insufficiency of land (ISL); Hazards in land purchasing (HLP); High cost of land registration (HCLR); High price of land (HPL); Unaware about the paper formalities of land (UAPF) have changed the attitudes of buyers (Bony and Rahman, 2014; Mohiuddin, 2014; Dewri, et al., 2012; Khaled, et al., 2012; Zadkarim and Emari, 2011; Barua, et al., 2010; Mollah, et al., 2009; Islam, 2008). Due to scarcity of open and vacant land, hazards in land purchasing, increasing the price of land (20 to 50 times in the last 15 years, Hasan, 1991) lack of public supports act as catalyst for Real Estate boom previously (labib, et al., 2013).

Urbanization and Population Pressure (UPP): Urban population growth (annual \%) in Bangladesh was last measured at 2.92 in 2013, according to the World Bank. Urban population refers to people living in urban areas as defined by national statistical offices. Urbanization growth rate has been increasing that ultimately stimulating the demand of apartments in city areas. There is a direct relationship between urbanization and demand for houses (Mollah, Haque and Pasha, 2009). Population of Bangladesh also increasing that indicates the huge prospects of housing sectors. There are some variables such Rapid increase in population (RIP); Rapid urban growth (RUG); Increases urbanization pressures (IUPS); Employment in urban areas (EUA); Good educational institutions in urban areas (GEIU) that creating the opportunities for the Real Estate sectors in Bangladesh. RIP, RUG, IUPS have been 
showed by Mohiuddin, 2014; Labib, et al., 2013; Dewri, et al., 2012; Barua, et al., 2010; Mollah, et al., 2009; Islam, 2008). Information about urbanization and populations in urban areas are shown in Table 1.

Table 1. Urban population and urban growth rate

\begin{tabular}{lllll}
\hline Indicators Year & 1990 & 2000 & 2010 & $\begin{array}{l}2013 \\
\text { Measured) }\end{array}$ \\
\hline \begin{tabular}{l} 
Urban population in Bangladesh \\
\hline $\begin{array}{l}\text { Urban Population Growth (Annual \%) } \\
\text { Bangladesh }\end{array}$
\end{tabular} & 22895166 & 30583777 & 41782489 & 46011671 \\
\hline $\begin{array}{l}\text { Population in the largest city (\% of urban } \\
\text { population) in Bangladesh }\end{array}$ & 28.6 & 3.5 & 2.9 & 2.92 \\
\hline
\end{tabular}

Source: http://www.tradingeconomics.com

Raising Prices Level (RPL): Simply Price is the amount of money that is charged for a product or services (Kotler and Armstrong, 2005). Price is a fundamental phenomenon for purchasing an apartment. Raising house rent (RHR); High labor cost (HLC); High price of building materials, (HPBM) construct the factor raising price level. Due to high price of building materials, high labor cost people would like to purchase apartment from Real Estate developers rather than build apartment (Mohiuddin, 2014; Labib, et al., 2013; Khaled, et al., 2012; Dewri, et al., 2012; Zadkarim and Emari, 2011; Barua, et al., 2010; Islam, 2008). A recent study conducted by Consumers Association of Bangladesh (CAB) shows that house rentals in Dhaka have more than doubled (249.62 percent) in the last 17 years. The rentals in Dhaka witnessed a jump in 1991 by over $23 \%$ and it continued for some years, finds the study. The increase was around 17\% in 2007 and 16\% in 2006 (Barua, et al., 2010). Raising the prices level of building materials have changed the attitudes of the buyers (Bony and Rahman, 2014; Mollah, et al., 2009).

Attitude (ATT): Attitude refers to "the degree to which a person has a favorable or unfavorable evaluation or appraisal of the behavior in question" (Ajzen, 1991). Attitude is the person's favor or disfavor toward an action (Tonglet, Phillips and Read, 2004, Al-Nahdi, 2004, 2008). Attitude is defined as a psychological tendency that is expressed by evaluating a particular entity with some degree of favor or disfavor (Ajzen and Fishbein, 1980). Attitude is also defined as the way individuals respond to and are disposed towards, an object (Yusliza and Ramayah, 2011). There is a strong and steady relationship between attitude and buying intention (Cronin and Taylor, 1992; Kim and Han, 2010; Gopi and Ramayah, 2007). Customers' buying attitude stalwartly influence the buyers' buying intention to purchase an apartment (Numraktrakul, Numraktrakul, Ngarmyarn and Panichpathom, 2012; Phungwong, 2010). Here the factor buying attitude is made of four items namely overall evaluation of Cultural changes (CABA) Population and urbanization pressures (PPABA); Land problem (SLAB); Raising prices levels (HPBBA).

Buying Intention (BI): Generally intention is an indication of a person's readiness to perform a given behavior, and it is considered to be the immediate antecedent of behavior (Shen, 2009). Intention is an indication of a person's willingness to perform the behavior, and it is an immediate antecedent of behavior (Nahdi, Habib and Albodour, 2015). Intention is the dependent variable which is predicted by an independent variable namely attitude (Ajzen and Fishbein, 1980; Ajzen, 1991; Taylor and Todd, 1995; Han and Kim, 2010). Therefore, in the case of apartment purchasing the intention to purchase is an antecedent of a purchase decision (Numraktrakul, Ngarmyarn and Panichpathom, 2012; Phungwong, 2010). In this study the buying intention is measured with the help of three items Commitment to buy and recommendation status (CBA); Feel loyalty to buy (FLB); Buying an apartment will be wise decision (WDF). Many scholars have measured buying intention with the help of the aforesaid dimensions (Al-Nahdi, et al., 2015; Tan, 2013; Numraktrakul, et al., 2012; Phungwong, 2010; Houng, Chen andTsai, 2007).

\section{Research Hypothesis:}

H1: Cultural changes have effects on buying attitude in the Real Estate industry.

H2: Due to insufficiency and high price of land buyers' buying attitudes have changed.

H3: Urbanization and population pressure have significant effects on buying attitude.

H4: Raising prices level of building materials have impacts on buying attitude of customers.

H5: Buying attitude influences the buying intention. 


\section{Objectives of the Study}

This study has been conducted for identifying the market factors and trends that have created opportunities for Real Estate sector along with following objectives:

- To explore present scenario and trends of Real Estate sector in Bangladesh.

- To assess market factors and variables that are antecedents of customers' buying attitude to purchase an apartment and have created opportunities for Real Estate sector.

- To examine relationships between market factors (antecedents of customers' buying attitude) and customers' buying attitudes in the Real Estate industry.

- To examine the relationship between customers' buying attitude and buying intention.

- To test the proposed Buying Intention Model with the help of SEM (Structural Equation Model).

\section{Research Methodology}

For this study primary and secondary both sources of data were used. Through literature review, discussion with industry experts and field survey with open ended questionnaire we have found more than 30 market variables that have been acting as catalyst for booming Real Estate sector in Bangladesh. After several round revisions a total number of 24 attributes were considered for designing final questionnaire. To test the reliability of the questionnaire a pilot survey was used. In pilot test 30 questionnaires were approached and collected from the respondents. To test the internal consistency, we applied the Cronbach's Alpha reliability analysis. The Cronbach's Alpha reliability was 0.73 that was acceptable.

\subsection{Sampling Design}

For this study all customers who have ability and willingness to buy an apartment, industry experts, student of Real Estate departments, researchers, teachers in Bangladesh were considered as target population. For this study we use two types of sampling techniques namely simple random sampling and convenient sampling. Initially, 200 questionnaires were distributed to the target populations for their responses but a total 153 usable questionnaires were collected.

\subsection{Data Collection and Analysis}

This study collected data through a survey conducted in the major areas of Dhaka using a detailed structured self-administered questionnaire. The respondents were asked about different attributes and situations about the market that have acted as reasons for purchasing apartment by using 7 point Likert scale. After collection of data Exploratory Factor Analysis (EFA) was applied using Principle Components Analysis (PCA) as method of convergence and Kaiser as method of normalization. Then CFA (Confirmatory factor Analysis) was conducted to test the model with factors identified through EFA. Finally the goodness of fit of the proposed model was tested using Structural Equation Modeling (SEM) with the help of AMOS-21. All the data were analyzed in Statistical Package for Social Science (SPSS; Version-21) integrated with AMOS, MS Excel and finally report is produced based on the analyzed data. Total research methodology has been summarized in below figure.

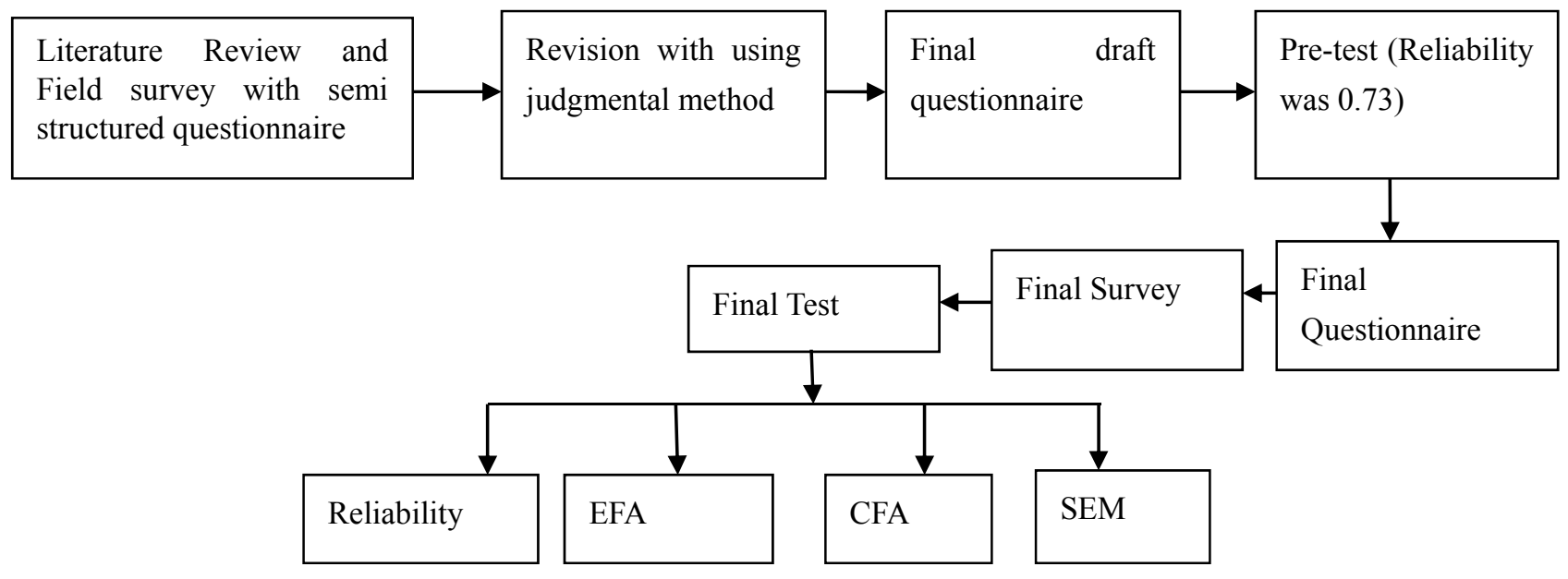

Figure 2. Summary of research methodology 


\section{Findings}

\subsection{Real Estate Trends, Growth Rate and Economic Contribution}

Private sector housing business started in 1970 in Bangladesh, where Dhaka (capital) was the main focus for the private sector investors. During the last two decades it has grown and now demand is rapidly increasing. Bangladesh is one of the fastest urbanizing countries as migration to the cities is very high. After 1990, a construction boom started in the country owing to the necessity for industrial buildings, corporate offices, housing units, roads and other types of infrastructure. Bangladesh has made major progress in recent years, with sustained macro-economic stability. According to Bangladesh Bureau of Statistics, the construction sector accounted for a record 9.1\% of GDP (Gross Domestic Product) in fiscal year 2012-13.

The building construction industry is considered as one of the fastest growing and largest sectors in Bangladesh. In 2008-2009, the construction sector employed 2.024 million people which is expected to rise to 2.88 million by this year (2015) and 3.32 million by 2020 (Report by WCC). The following table shows the comparison between overall GDP growth and growth of Real Estate, renting and business services from (2002-2010) in Bangladesh.

Table 2. Comparison between overall GDP growth and growth of real estate, renting and business services from (2002-2010) in Bangladesh

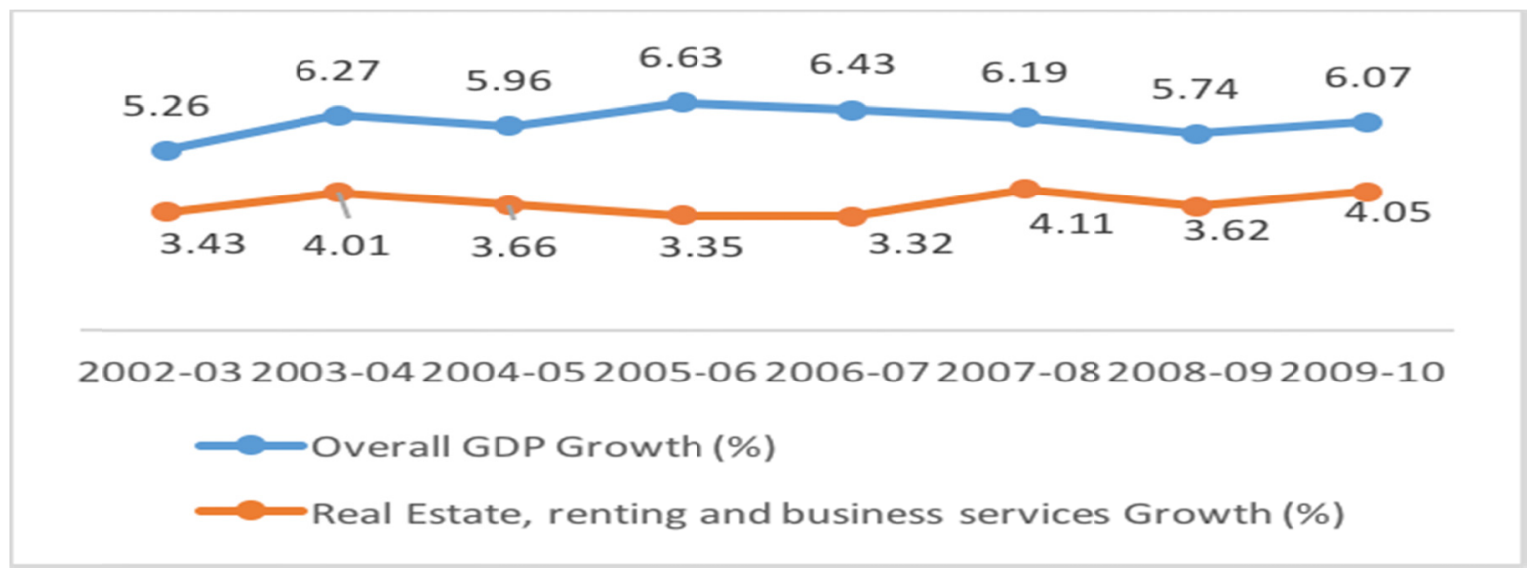

Source: http://www.lightcastlebd.com

The growth rate of Real Estate, Renting and Business service sector has increased over the 2002-2010 period. However, compared to overall GDP growth, this sector expanded at a slower rate, which explains the downward trend in Real Estate as a percentage of overall GDP. The business of real estate had very slow growth rate in the first decade. The industry grew in a moderate pace since 2006, but between 2008 and 2010 the growth rate was exponential. Total volume of Real Estate, renting and business services and GDP contribution trend analysis are given below:

Table 3. Growth, GDP contribution, trend analysis and total volume of real estate business (2001-2009)

\begin{tabular}{llll}
\hline Year & Total volume (Crore Taka) & GDP Contribution (\%) & Growth (\%) \\
\hline $2001-02$ & 19440 & 8.63 & - \\
\hline $2002-03$ & 20106 & 8.48 & 3.43 \\
\hline $2003-04$ & 20913 & 8.30 & 4.01 \\
\hline $2004-05$ & 21678 & 8.12 & 3.66 \\
\hline $2005-06$ & 22404 & 7.87 & 3.35 \\
\hline $2006-07$ & 23147 & 7.64 & 3.32 \\
\hline $2007-08$ & 24097 & 7.49 & 4.11 \\
\hline $2008-09$ & 24970 & 7.34 & 3.62 \\
\hline $2009-10$ & 25981 & 7.20 & 4.05
\end{tabular}

Source: Mohiuddin, 2014 and Statistical Year Book-2010 
Table 4. Growth, GDP contribution trend analysis and total volume of real estate business (2010-2014)

\begin{tabular}{llll}
\hline Year & $\begin{array}{l}\text { Total volume (Million } \\
\text { Taka) }\end{array}$ & GDP Contribution (\%) & Growth (\%) \\
\hline $2010-11$ & 457,896 & 7.41 & 3.88 \\
\hline $2011-12$ & 475,864 & 7.22 & 3.92 \\
\hline $2012-13$ & 495,089 & 7.07 & 4.04 \\
\hline $2013-14$ & 516,092 & 6.95 & 4.24 \\
\hline
\end{tabular}

Source: Bangladesh Bureau of Statistics, 2015

\subsection{Scale Reliability}

To test the internal consistency of each of the attributes, items of the customers' buying attitudes, and buying intention we applied the Cronbach's Alpha reliability analysis. In this study a total 24 items (17 items from the market factors (antecedents of buying attitude that have created opportunities); 4 items from the customers' buying attitude and 3 items from buying intention) were considered. In scale reliability analyze we found that the value of Alpha is $\mathbf{0 . 7 0 4}$ which is highly reliable (Nunnaally, 1978).

Table 5. Showing reliability coefficients for each variable

\begin{tabular}{ccc}
\hline & Reliability Statistics & \\
\hline Measure & Cronbach's Alpha & N of items \\
\hline Market Factors & 0.602 & 17 \\
\hline Customers' Buying Attitude & 0.427 & 04 \\
\hline Buying Intention & 0.731 & 03 \\
\hline
\end{tabular}

\subsection{Exploratory Factor Analysis}

In order to identify market factors and attributes that have changed the attitude of customers to buy apartment we conducted an exploratory factor analysis. Initially we considered 24 variables.

Kaiser-Meyer-Olkin (KMO) measure of sample adequacy test was applied on market factors to test whether the sample was adequate to consider the data was normally distributed or not. The KMO value was $\mathbf{0 . 6 7 5}$ indicating that the sample size was adequate to consider the data normally distributed as the KMO values above 0.5 are considered to indicate normality of data. Bartlett's Test of Sphericity was used to test the null hypotheses that the variables in the study are not correlated. The Chi-Square test value was 879.692 , which was significant at $\mathbf{0 \%}$ level of significant. The test indicated that variables in the study are correlated and rejected the null hypothesis (The population correlation matrix is an identity matrix). Therefore, the data was suitable for factor analysis.

Table 6. Showing the KMO Test results

\begin{tabular}{lll}
\hline KMO and Bartlett's Test & \\
\hline Kaiser-Meyer-Olkin (KMO) Measure of Sampling adequacy. & 0.675 \\
\hline Bartlett's Test of Sphericity & Approx. Chi- Square & 879.692 \\
\cline { 2 - 3 } & Df & 91 \\
\cline { 2 - 3 } & Sig. & 0.000 \\
\hline
\end{tabular}

\subsection{Market Factors}

The principal component analysis was used as the extraction method associated with the rotation method of Varimax with Kaiser Normalization. This study has examined communalities of each attribute accounted for the research. Initially 17 items were approached for this test. This study did not find absolute communalities score for all items. Hence, 4 items that scored less than 0.4 were dropped from the data set. Since data were collected from field survey, the authors considered current score level for 13 items included in 4 factors. Therefore, 4 factors were extracted on the basis of Eigen values and variance explained by them as well as the judgment of researchers. The factors were named 
based on communality of all the items that converged on that factor. Finally this study identified four market factors namely cultural changes, land problem, urbanization and population pressures, raising prices level that robustly influence the buyers' attitude in purchasing apartment in Bangladesh.

6.5 Information Related to EFA

All the information related to EPA are shown in Table 7:

Table 7. All information related to EFA (Exploratory Factor Analysis)

\begin{tabular}{|c|c|c|c|c|c|c|c|c|c|}
\hline 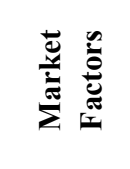 & Attributes & Mean & $\begin{array}{l}\text { Standard } \\
\text { Deviation }\end{array}$ & $\begin{array}{l}\text { Factor } \\
\text { Loading }\end{array}$ & $\begin{array}{l}\text { Factor } \\
\text { Mean }\end{array}$ & $\begin{array}{l}\text { Cronb } \\
\text { ach's } \\
\text { Alpha }\end{array}$ & $\begin{array}{l}\text { Eigen } \\
\text { Value }\end{array}$ & $\begin{array}{c}\text { Varianc } \\
\text { e }(\%)\end{array}$ & $\begin{array}{c}\text { Cumula } \\
\text { tive } \\
\text { Varianc } \\
\text { e }(\%)\end{array}$ \\
\hline \multirow{3}{*}{ 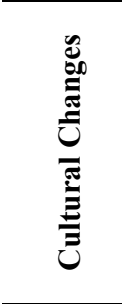 } & $\begin{array}{l}\text { Re-structuring the } \\
\text { Household Pressure/ } \\
\text { Single Family Units }\end{array}$ & 5.1503 & .97178 & .954 & \multirow{3}{*}{5.146} & \multirow{3}{*}{0.963} & \multirow{3}{*}{2.638} & \multirow{3}{*}{20.560} & \multirow{3}{*}{20.560} \\
\hline & Apartment Culture & 5.1634 & .92805 & .891 & & & & & \\
\hline & $\begin{array}{l}\text { Project Facilities Are } \\
\text { Demanded by Buyers }\end{array}$ & 5.1242 & .91278 & .861 & & & & & \\
\hline \multirow{4}{*}{ 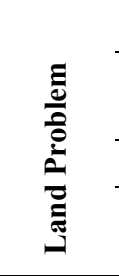 } & Insufficiency of Land & 5.2353 & 1.02447 & .785 & \multirow{4}{*}{5.670} & \multirow{4}{*}{0.688} & \multirow{4}{*}{2.454} & \multirow{4}{*}{19.124} & \multirow{4}{*}{39.684} \\
\hline & $\begin{array}{l}\text { Hazards in Land } \\
\text { Purchasing }\end{array}$ & 5.5098 & .98754 & .729 & & & & & \\
\hline & High Price of Land & 6.1830 & .96271 & .661 & & & & & \\
\hline & $\begin{array}{l}\text { Unaware about the Paper } \\
\text { Formalities of Land }\end{array}$ & 5.7516 & 1.01490 & .596 & & & & & \\
\hline \multirow{3}{*}{ 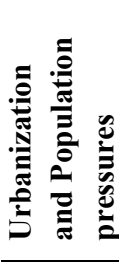 } & $\begin{array}{l}\text { Rapid Increase in } \\
\text { Population }\end{array}$ & 5.6340 & .95112 & .790 & \multirow{3}{*}{5.353} & \multirow{3}{*}{0.707} & \multirow{3}{*}{1.576} & \multirow{3}{*}{12.285} & \multirow{3}{*}{51.969} \\
\hline & $\begin{array}{l}\text { Increasing Urbanization } \\
\text { Pressures }\end{array}$ & 5.8889 & .95666 & .779 & & & & & \\
\hline & $\begin{array}{l}\text { Rapid Growth of } \\
\text { Urbanization }\end{array}$ & 4.5359 & 1.00673 & .659 & & & & & \\
\hline \multirow{3}{*}{ 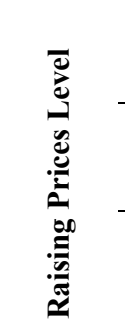 } & $\begin{array}{l}\text { High Prices of Building } \\
\text { Materials }\end{array}$ & 5.3987 & .98234 & .711 & \multirow{3}{*}{5.281} & \multirow{3}{*}{0.248} & \multirow{3}{*}{1.120} & \multirow{3}{*}{8.727} & \multirow{3}{*}{60.697} \\
\hline & High Labor Cost & 5.4183 & .97072 & .618 & & & & & \\
\hline & Raising House Rent & 5.0261 & .94554 & .470 & & & & & \\
\hline
\end{tabular}

Extraction Method: Principal Component Analysis.

Rotation Method: Varimax with Kaiser Normalization.

a. Rotation converged in 4 iterations

\subsection{Structural Equation Modeling (SEM) and Hypotheses Testing}

SEM was conducted to evaluate the hypotheses formulated at the initial stage of the study as well as to test the goodness of Fit of the hypothesized model. Here the full structural equation model is considered and hypotheses to be tested relates to the pattern of causal structure linking several market factors that bear on the construct of customers' buying attitude. Results of the hypotheses are shown in Table 8 . 
Table 8. Result of the research hypotheses

\begin{tabular}{|c|c|c|c|c|c|c|c|c|}
\hline $\begin{array}{l}\text { Hypot } \\
\text { hesis }\end{array}$ & $\begin{array}{l}\text { Dependent } \\
\text { Variable }\end{array}$ & $\begin{array}{l}\text { Independent } \\
\text { Variable }\end{array}$ & Estimate & $\begin{array}{l}\text { Standardi } \\
\text { zed } \\
\text { Estimate }\end{array}$ & SE & C.R. & $\mathrm{P}$ & $\begin{array}{l}\text { Decisio } \\
\mathrm{n}\end{array}$ \\
\hline H1 & $\begin{array}{l}\text { Buying } \\
\text { Attitude }\end{array}$ & Cultural Changes & .010 & .03 & .030 & .327 & .744 & $\begin{array}{l}\text { Rejecte } \\
\mathrm{d}\end{array}$ \\
\hline $\mathrm{H} 2$ & $\begin{array}{l}\text { Buying } \\
\text { Attitude }\end{array}$ & Land Problem & .239 & .42 & .083 & 2.883 & .004 & $\begin{array}{l}\text { Support } \\
\text { ed }\end{array}$ \\
\hline H3 & $\begin{array}{l}\text { Buying } \\
\text { Attitude }\end{array}$ & $\begin{array}{l}\text { Urbanization and } \\
\text { Population } \\
\text { Pressures }\end{array}$ & .121 & .30 & .047 & 2.556 & .011 & $\begin{array}{l}\text { Support } \\
\text { ed }\end{array}$ \\
\hline $\mathrm{H} 4$ & $\begin{array}{l}\text { Buying } \\
\text { Attitude }\end{array}$ & $\begin{array}{l}\text { Raising } \\
\text { Level }\end{array}$ & .269 & .33 & .249 & 1.082 & .279 & $\begin{array}{l}\text { Rejecte } \\
\mathrm{d}\end{array}$ \\
\hline H5 & $\begin{array}{l}\text { Buying } \\
\text { intention }\end{array}$ & $\begin{array}{l}\text { Buying } \\
\text { Attitude }\end{array}$ & .840 & .68 & .221 & 3.807 & $* * *$ & $\begin{array}{l}\text { Support } \\
\text { ed }\end{array}$ \\
\hline
\end{tabular}

In testing the hypothesized relationships among the market factors (antecedents of customers' buying attitude) and customers' buying attitude (Buying Attitude), we conducted the CFA. In CFA we found that the Cultural Changes (CC), Raising Prices Level (RPL) have not significant influence on customers' buying attitude in context of apartment purchasing. The overall fit of a final hypothesized model was tested by using the maximum likelihood, goodness of fit indices and modification indices to ensure that final model has good fit to the data. The Chi-square statistic provided in the AMOS (a software package for SEM, Version-21) output and their fit indices such as the ratio of Chi-square to Degrees of Freedom (df), Goodness-of-Fit Index (GFI), The Root Mean Square Error of Approximation (RMSEA), and Parsimonious Fit Index (PFI). Chi square and Degree of freedom were 283.409 and 166. The Cmin/df value should be smaller than 2 to consider the model having good fit, for the current study the Cmin/df value is 1.707. Goodness of fit indices of the final hypothesized model of Real Estate Buyers' Buying Intention is summarized in Table 9.

Table 9. Key goodness-of-fit indices

\begin{tabular}{|c|c|c|c|}
\hline Type of Fit & Key Index & Acceptable Level & In Proposed Model \\
\hline \multirow[t]{4}{*}{ Absolute Fit } & Chi-Square $\left(x^{2}\right)$ & $2 \mathrm{df} \leq x^{2} \leq 3 \mathrm{df}$ & 283.409 \\
\hline & $\begin{array}{l}\text { Root Mean Square Error } \\
\text { of } \\
\text { Approximation (RMSEA) }\end{array}$ & $0.05 \leq \mathrm{RMSEA} \leq .08$ & .068 \\
\hline & $\begin{array}{l}\text { Goodness of } \\
\text { Fit Index (GFI) }\end{array}$ & $0.90 \leq \mathrm{GFI} \leq 0.95$ & 0.846 \\
\hline & $\begin{array}{l}\text { Root Mean Squared } \\
\text { Residual } \\
\text { (RMR) }\end{array}$ & $0.05 \leq \mathrm{RMR} \leq .10$ & 0.073 \\
\hline \multirow[t]{3}{*}{ Parsimonious Fit } & $\begin{array}{l}\text { Parsimonious Normed Fit } \\
\text { Index (PNFI) }\end{array}$ & PNFI $>0.5$ & 0.675 \\
\hline & $\begin{array}{l}\text { Parsimonious } \\
\text { goodness-of-fit } \\
\text { index (PGFI) } \\
\end{array}$ & PGFI $>0.5$ & 0.668 \\
\hline & $\begin{array}{l}\text { Parsimonious Fit } \\
\text { Index (PCFI) }\end{array}$ & PCFI $>0.5$ & 0.777 \\
\hline
\end{tabular}

Source: Adapted from Kline, 2005; Engel and Moosbrugger, 2003; Byrne, 2001; Kelloway, 1998. 
Finally we can conclude that the proposed hypothetical model of buying intention in context of apartment buying has a good fit. The model that has been generated from the output of AMOS is shown in Figure 3.

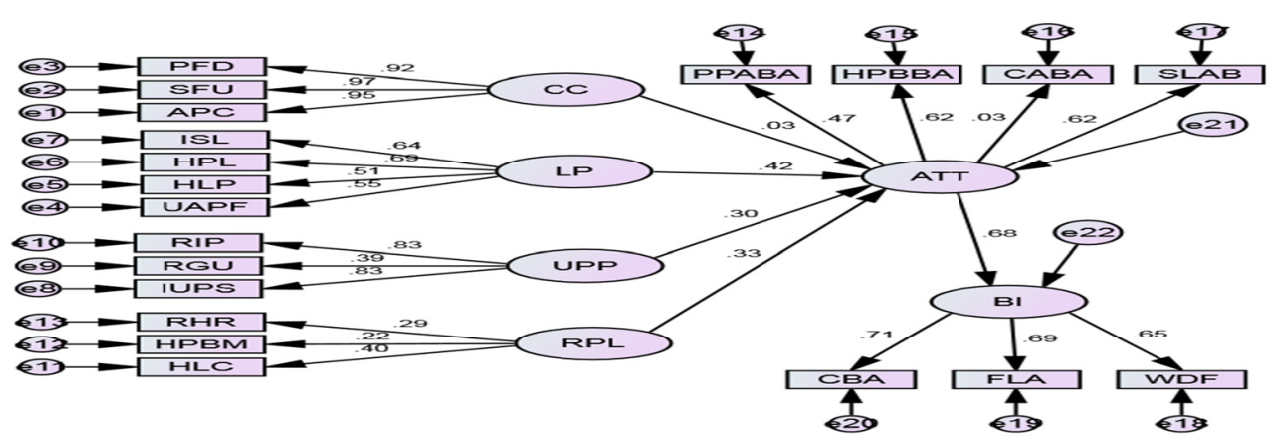

Figure 3. Model of buying intention

Final model of buying intention in Figure 3 indicating that market factors land problem, urbanization and population pressures act as catalyst for increasing the demand of readymade apartment in urban areas and that have significant impact on customers' buying attitude. It also indicates customers' buying attitude has significant impact on the buying intention of buyers in purchasing an apartment.

\section{Conclusion and Implications}

Shelter is the one of the fundamental needs of people of any country. Government of every country tries to provide the housing facilities to general public. In Bangladesh approximately 7 million people have been facing housing deficiency where 4 million in the urban areas and 3 million in the rural areas. It is impossible for any government to ensure $100 \%$ housing facilities to all the public. Dhaka is grappling with severe shortages of affordable housing due to immense migration from the countryside into new urban centers for that reasons Dhaka city requires between $55,000-83,000$ housing units each year, whereas all public and private efforts together can only produce 25,000 housing units a year (Bashar, 2013, Urban Dialogue, Habitat for Humanity) http://www.habitatbangladesh.org/files/Urban\%20Housing\%20HFHBD.pdf

To cope up with this situation many private Real Estate developers with very few provision of government housing have been trying to meet the demand of housing/ shelter for the last more than twenty years in Bangladesh. Therefore the government of this country should come forward to make a public private partnership (PPP) with private real estate developers to develop the real estate sector in a sustainable way. The Real Estate developers should be aware about the needs and choices of the customers of apartment.

Our research has revealed four market factors namely cultural changes, land problem, urbanization and population pressure and raising the prices level that act as a catalyst for changing the attitudes of Real Estate buyers. Cultural changes have been taken place in the areas like restructuring of household, Project facilities are demanding by the customers, influence of western culture. Land is fixed so in urban areas the proper use of land should be ensured. Government should take some measures to avoid the hazards in land purchasing. Real Estate developers should be aware about the market factors that have been changing the trends of industry as well as consumers' preferences. Sometimes Real Estate developers involve with malpractices and try to cheat with the customers. To ensure customer satisfaction and sustainable development of the Real Estate industry that malpractices should be avoided. Besides the aforesaid facilities customers of apartment would like to get prompt services, timely handover of the apartment, empathy, responsive behavior and after sales services from the developers. Identifying customers' needs, choices and preferences are crucial tasks for developing effective Real Estate marketing strategies. The findings of the study will help to understand the buying attitudes and behavior of customers and ultimately lead to develop the sustainable marketing strategies. 


\section{Limitation and Further Research}

The present study is not out of limitations. Some constraints are appended like our sample size was limited. Convenience sampling technique was used to collect data which is not well enough to serve the purpose. The buyers were too busy to provide researchers much time for responding to the questionnaires. The authors did not have the opportunity to compare the market factors among the various locations. So further research is encouraged to consider more samples as well as compare market factors from location to locations.

\section{References}

Ajzen, I. (1991). The theory of planned behavior. Organizational Behavior and Human Decision Processes, 50, 179-211. http://dx.doi.org/10.1016/0749-5978(91)90020-T

Ajzen, I., \& Fishbein, M. A. (1980). Understanding attitudes and predicting social behavior. Englewood Cliffs, NJ: Prentice Hall.

Al-Nahdi, T.S., Habib, S.A., \& Albdour, A.A. (2015). Factors influencing the intention to purchase real estate in Saudi Arabia: moderating effect of demographic citizenship. International Journal of Business and Management, 10(4), 35-48. http://dx.doi.org/10.5539/ijbm.v10n4p35

Barua, S., Mridha, A. H. A., \& Khan, R. H. (2010). Housing real estate Sector in Bangladesh: present status and policies implications. ASA University Review, 4(1), 240-253.

Benjamin, D. J. (2003). The environment and performance of real estate. Journal of Real Estate Literature, 11, 279-324. http://dx.doi.org/10.2469/dig.v34.n2.1404

Bettman, J. R., Luce, M. F., \& Payne, J. W. (1998). Constructive consumer choice processes. Journal of Consumer Research, 25(3), 187-217. http://dx.doi.org/10.1086/209535

Bhakar, S., Bhakar, S. S., \& Dubey, A. (2015). Analysis of the factors affecting customers' purchase intention: The mediating role of customer knowledge and perceived value. Advances in Social Sciences Research Journal, 2(1), 87-101. http://dx.doi.org/10.14738/assrj.21.139

Bony, S. Z., \& Rahman, S. (2014). Practice of real estate business in Bangladesh: Prospects and Problems of high rise building. IOSR Journal of Business and Management (IOSR-JBM), 16(7), 1-7. http://dx.doi.org/10.9790/487X-16740107

Dewri, L. V., Amin, M. M., Sen, M. S., \& Faridi, R. (2012). A comprehensive study on the real estate sector of Bangladesh.

Retrieved

from http://www.rehabbd.org/rehab_new_Comprehensive_Study_On_The_Real_Estate_Sector_Of_Bangladesh.pdf

Hadad, M., Judehand, M., \& Hadad, S. (2011). Factors affecting buying Behavior of an apartment an empirical investigation in Amman, Jordan. Research Journal of Applied Sciences, Engineering and Technology, 3(3), 234-239. Retrieved from https://doaj.org/article/f741f9f178754ffc95e51f1aac020542

Islam, M. S. (2012). Factors determining the real estate company's performance in Bangladesh: Evidence from Adept consultants ltd. Company. Internship Report, Independent University of Bangladesh, Bangladesh. Retrieved from www.sb.iub.edu.bd/internship/autmn2012/0830063.pdf

Islam, M. S., \& Hossain, A. (2008). Operations of Bangladesh housing industry: An uncertain supply chain model. The AIUB Journal of Business and Economics (AJBE), 7, 20-31.

Islam, M. T. (2008). Real estate market in Bangladesh: Development and current practice. Master of Science Thesis Number: 428, Division of Building and Real Estate Economics, Department of Real Estate and Construction Management KTH, The Royal Institute of Technology Stockholm, Sweden. Retrieved from https://www.kth.se/polopoly_fs/1.177258!/Menu/general/column-content/attachment/428.pdf

Khaled, M. C., Sultana, T., Biswas, S. K., \& Karan, R. (2012). Real estate industry in Chittagong (Bangladesh): A survey on customer perception and expectation. Developing Country Studies, 2(2), 38-45.

Khan, M. S., \& Barua, S. (2009, December). The Dynamics of residential real estate sector in Bangladesh: Challenges faced and policies sought. Journal of Management Studies, University of Dhaka, 1-26.

Kothari, C. R. (1990). Research Methodology: Methods and Techniques ( $2^{\text {nd }}$ ed.). New Delhi, India, New age international publishers.

Kotler, P. \& Amstrong, G. (2005) Principles of Marketing (11th ed.). New Jersey: Prentice Hall. 
Labib, S.M., Bhuiya, M. M. R., \& Rahaman, M. Z. (2013). Location and size preference for apartments in Dhaka and prospect of real estate market. Bangladesh Research Publications Journal, 9(2), 87-96.

Lee, Y., Chen, C.Y., Huang, C. L., Chang, L. Y., \& Udomjarumanee, K. (2009). A comparison of service quality perception in real estate brokerage between Taiwan and Thailand. The Journal of International Management Studies, 4(3), 10-24.

Leiser, K., \& Ghor, A. P. (2011). The determinants of international commercial real estate investments. The working paper - WP-935, IESE Business School- University of Navarra. Retrieved from http://www.iese.edu/research/pdfs/DI-0935-E.pdf

Malhotra, N.K. (2006). Marketing Research: An Applied Orientation (5 $5^{\text {th }}$ ed.), New Delhi, India, Prentice-Hall of India Private Limited.

Mohiuddin, M. (2014). The real estate business in Dhaka city: Growth and contribution to the economy of Bangladesh. IOSR Journal of Business and Management (IOSR-JBM), 16(4), 58-60.

Mollah, M. M. H., Haque, I., \& Pasha, S. H. A. (2009). Factors influencing apartment buying decision: An analysis of company and customer. Southeast University Journal of Business Studies, V(2), 109-117.

Nelson, T., \& Rabianski, J. (1988). Consumer preferences in housing market analysis: An application of multidimensional scaling techniques. Real Estate Economics, 16(2), 138-159. http://dx.doi.org/10.1111/1540-6229.00451

Numraktrakul, P., Ngarmyarn, A., \& Panichpathom, S. (2012). Factors affecting green housing purchase. In 17th International Business Research Conference. Toronto, Canada.

Phungwong, O. (2010). Factors influencing home purchase intention of Thai single people. Doctoral dissertation, International graduate school of business, University of South Australia, Adelaide, Australia. Retrieved from https://ornticha.wikispaces.com/file/view/Assignment+3.doc

Preko, A., Agbanu, S. K., \& Feglo, M. (2014). Service delivery, customer satisfaction and customer delight in the real estate business. Evidence from Elite Kingdom investment and consulting company Ghana. European Journal of Business and Management, 6(3), 71-83.

Sekaran, U. (2003). Research methods for business: A skill-building approach $\left(4^{\text {th }}\right.$ ed.). New York: John Wiley and Sons, Inc.

Shahin, A., Jarib, H., \& Samea, M. (2010). Developing the models of service quality gaps: A critical discussion. Journal of Business Management and Strategy, 1(1), 1-11. http://dx.doi.org/10.5296/bms.v1i1.395

Tonglet, M., Phillips, P. S., \& Read, A. D. (2004). Using the Theory of Planned Behavior to investigate the determinants of recycling behavior: A case study from Brixworth, UK. Resources Conservation and Recycling, 41(3), 191-214. http://dx.doi.org/10.1016/j.resconrec.2003.11.001

Yusliza, M. Y., \& Ramayah, T. (2011). Explaining the intention to use electronic HRM among HR professionals: Results from a pilot study. Australian Journal of Basic and Applied Sciences, 5(8), 489-497.

Zadkarim, S., \& Emari, H. (2011). Determinants of satisfaction in apartment industry: Offering a model. Journal of civil engineering and urbanization, 1(1), 15-24.

Zadkarim, S., Emari, H., Sanatkar, S., \& Barghlame, H. (2011). Environmental quality as an important dimension of customer satisfaction in apartment industry. African Journal of Business Management, 5(17), 7272-7283. http://dx.doi.org/10.5897/AJBM10.995 